\title{
NIAT KONSUMEN LANSIA MENGONSUMSI SUPLEMEN MULTIVITAMIN YANG DIMODERASI MOTIF UNTUK SEHAT
}

\author{
Anak Agung Gede Satrya Anggara Putra ${ }^{1}$ \\ Ni Wayan Sri Suprapti ${ }^{2}$ \\ Ni Nyoman Kerti Yasa ${ }^{3}$ \\ ${ }^{1}$ Fakultas Ekonomi dan Bisnis Universitas Udayana, Bali, Indonesia \\ e-mail: agungsatrya93@gmail.com \\ ${ }^{2}$ Fakultas Ekonomi dan Bisnis Universitas Udayana, Bali, Indonesia \\ ${ }^{3}$ Fakultas Ekonomi dan Bisnis Universitas Udayana, Bali, Indonesia
}

\begin{abstract}
ABSTRAK
Tujuan dari penelitian ini adalah menjelaskan pengaruh sikap konsumen, aspek normatif, aspek informasi, dan persepsi kontrol keperilakuan terhadap niat mengonsumsi suplemen multivitamin, serta peran motif untuk sehat sebagai variabel moderasi. Populasi dalam penelitian ini adalah para lanjut usia yang memiliki niat mengonsumsi suplemen multivitamin. Teknik penentuan sampel dilakukan dengan mempergunakan metode purposive sampling dengan responden sebanyak 133 orang lansia yang berdomisili di Kota Denpasar. Kuesioner sebagai instrumen penelitian dan analisis regresi moderasi sebagai teknik analisis penelitian ini. Hasil penelitian menunjukkan bahwa sikap konsumen dan aspek normatif berpengaruh negatif dan signifikan terhadap niat mengonsumsi suplemen multivitamin, sedangkan aspek informasi dan persepsi kontrol keperilakuan berpengaruh positif dan signifikan terhadap niat mengonsumsi suplemen multivitamin. Motif untuk sehat mampu memoderasi pengaruh sikap konsumen, aspek normatif, aspek informasi, dan persepsi kontrol keperilakuan terhadap niat mengonsumsi suplemen multivitamin.
\end{abstract}

Kata Kunci : sikap konsumen, aspek normatif, aspek informasi, persepsi kontrol keperilakuan, motif untuk sehat, niat mengonsumsi.

\section{ABSTRACT}

The purpose of this study is to explain the influence of consumer attitudes, normative aspects, aspects of information, and perception of behavioral control on intentions of taking multivitamin supplements, as well as the role of motive for healthy as a moderating variable. The population in this study were the elderly who had the intention of taking multivitamin supplements. The technique of determining the sample was done by using purposive sampling method with 133 elderly people and domiciled in Denpasar as respondent. Questionnaire as research instrument and the moderated regression analysis as analysis technique in this research. The results showed that consumer attitudes and normative aspects had a negative and significant effect on intention of multivitamin supplement, while the information aspect and perception of behavior control had positive and significant effect on intention of multivitamin supplement. Motives for healthy are able to moderate the influence of consumer attitudes, normative aspects, aspects of information, and perceptions of behavioral control against intention to consume multivitamin supplements.

Keywords: consumer attitude, normative aspect, information aspect, perception of behavioral control, motive for healthy, intention to consume. 


\section{PENDAHULUAN}

Mengonsumsi makanan pokok telah menjadi suatu kebiasaan turuntemurun yang dikonsumsi secara terus menerus bagi setiap orang. Selain mengonsumsi bahan makanan pokok, seseorang sering kali mengonsumsi bahan makanan tambahan seperti suplemen multivitamin yang digunakan untuk melengkapi keseluruhan nutrisi yang dibutuhkan oleh tubuh. Konsumsi produk ini mengalami kecenderungan yang terus meningkat. Hal ini ditunjukkan oleh capaian penjualan produk tersebut di Indonesia selama lima tahun mulai Tahun 2008 sampai Tahun 2013. Selama lima tahun tersebut, penjualan meningkat sebanyak 94 persen yaitu dari Rp 7,2 miliar pada Tahun 2008 menjadi Rp 13,98 miliar pada Tahun 2013. Beberapa merek suplemen multivitamin yang telah beredar di Indonesia di antaranya Appeton Essential MV21, Enervon-C, Kirkland Mature Multi, Nature's Plus Golden Years, Nature's Way Complete Daily Multivitamin, Nutrafor Gold, Nutrimax Complete Multivitamin \& Minerals, dan Renovit Gold.

Konsumsi suplemen multivitamin umumnya meningkat seiring dengan bertambahnya usia (Dickinson dan MacKay, 2014). Hal ini tentunya didukung oleh peningkatan pertumbuhan penduduk lansia di Indonesia. Berdasarkan data proyeksi jumlah penduduk lansia di Indonesia yang dipublikasi oleh Depkes (2014) menunjukkan adanya peningkatan selama periode tahun 2000 sampai tahun 2020. Jumlah penduduk lansia meningkat sebanyak 4,16 persen yaitu dari 14,4 juta jiwa $(7,18)$ pada Tahun 2000 menjadi 22,8 juta jiwa $(11,34)$ pada Tahun 2020. Jika dilihat dari sebaran penduduk lansia di Indonesia, kota Denpasar 
merupakan salah satu kota dengan jumlah penduduk lanjut usia tertinggi (Badan Pusat Statistik, 2016). Dengan demikian, tidak menutup kemungkinan penduduk lansia di Kota Denpasar memiliki perilaku konsumsi suplemen multivitamin.

Alasan seseorang untuk mengonsumsi suplemen multivitamin sangat beragam dan kompleks misalnya risiko kesakitan meningkat seperti kanker, penyakit infeksi, dan penyakit kronik (Fatmah, 2006). Namun, terdapat pendekatan yang digunakan untuk menjelaskan suatu perilaku tertentu yaitu Theory of Planned Behavior (TPB). TPB memaparkan bahwa sebuah perilaku dilakukan karena setiap individu memiliki niat untuk berperilaku yang dipengaruhi oleh tiga komponen yaitu sikap konsumen, norma subyektif, dan kontrol perilaku (Siahaan et al., 2015). Sebelumnya, beberapa penelitian telah menggunakan TPB untuk memprediksi niat mengonsumsi suplemen multivitamin. Penelitian yang dilakukan Petraszko (2013) menunjukkan sikap, norma subyektif, dan persepsi kontrol keperilakuan secara bersama-sama mempengaruhi niat mengonsumsi suplemen multivitamin. Namun, penelitian Zychowicz dan Pilska (2006) menunjukkan bahwa norma subyektif menjadi prediktor yang lemah terhadap niat mengonsumsi suplemen multivitamin. Oleh karena itu, Mangleburg et al. (2004) menyarankan pengaruh sosial dalam konsep TPB dapat diperluas mencakup aspek normatif (normative influence) dan aspek informasi (informational influence).

Sikap konsumen memiliki korelasi dengan niat mengonsumsi suplemen multivitamin (Yap et al., 2014). Niat konsumen untuk mengonsumsi suplemen multivitamin akan muncul jika konsumen memiliki sikap positif terhadap 
konsumsi suplemen multivitamin dan berpikir bahwa dengan mengonsumsinya dapat menjaga kesehatannya. Selain sikap konsumen, niat mengonsumsi suplemen multivitamin juga dipengaruhi oleh pengaruh sosial yaitu aspek normatif dan informasi. Aspek normatif menunjukkan kecenderungan individu untuk menyesuaikan diri dengan harapan kerabat atau orang terdekat (Ozer, 2012). Keinginan konsumen untuk berperilaku sesuai dengan harapan orang terdekat seperti keluarga, sahabat, dan penasehat kesehatan akan mempengaruhi niatnya dalam proses pengambilan keputusan mengonsumsi suplemen multivitamin. Aspek informasi menunjukkan kecenderungan individu untuk menerima informasi tentang suatu produk dengan cara mencari informasi dan mengamati perilaku orang lain (Silvera et al., 2008). Keinginan seseorang untuk menjadi benar dan memiliki pemahaman yang tepat dalam konteks sosial, maka membuat seseorang cenderung untuk bergantung pada orang lain sebagai sumber informasi (Yap et al., 2014). Disamping itu, memperoleh sumber informasi yang akurat dan terpercaya dapat mempengaruhi niat seseorang mengonsumsi suplemen multivitamin.

Niat mengonsumsi suplemen multivitamin tidak muncul begitu saja, terdapat faktor internal yang mendorong individu itu sendiri yang disebut sebagai kontrol perilaku. Persepsi kontrol keperilakuan menunjukkan persepsi individu mengenai ada atau tidak adanya faktor yang mendukung maupun menghambatnya untuk menampilkan perilaku tertentu (Saud, 2016). Pickett et al. (2012) menunjukkan bahwa persepsi kontrol keperilakuan berpengaruh terhadap niat mengonsumsi suplemen multivitamin. Hal ini berarti seseorang yang memiliki 
persepsi bahwa perilaku konsumsi suplemen multivitamin mudah untuk dilakukan dan yakin ia memiliki sumber daya ataupun kesempatan, maka orang tersebut cenderung memiliki niat yang kuat untuk mengonsumsi suplemen multivitamin. Hasil wawancara terhadap 25 orang lansia di Kota Denpasar menunjukkan bahwa sebanyak 32 persen responden menyatakan mengonsumsi suplemen multivitamin tidak memiliki manfaat atau khasiat bagi tubuhnya dan harga produk suplemen multivitamin yang sulit untuk dijangkau oleh lansia. Namun, sebanyak 68 persen responden menyatakan bahwa mereka berniat mengonsumsi suplemen multivitamin dengan alasan bahwa mereka pikir mengonsumsi suplemen multivitamin bermanfaat bagi kesehatannya, menerima saran untuk mengonsumsi suplemen multivitamin dari orang terdekat, memperoleh informasi terkait manfaat produk suplemen multivitamin dari orang lain, dan memiliki sumber daya ataupun kesempatan untuk mengonsumsinya.

Beberapa hasil penelitian menunjukkan bahwa sikap konsumen, aspek normatif, aspek informasi, dan persepsi kontrol keperilakuan tidak berpengaruh terhadap niat mengonsumsi suplemen multivitamin (Tang dan Farn, 2005; Mynhardt, 2009; Grandon et al., 2011; Penz dan Hogg, 2011). Noor et al. (2014) menyatakan bahwa motif untuk sehat mampu memoderasi pengaruh sikap konsumen, aspek normatif, aspek informasi, dan persepsi kontrol keperilakuan terhadap niat mengonsumsi suplemen multivitamin. Penelitian ini akan mereplikasi model penelitian dari Noor et al. (2014), namun menyederhanakan kembali variabel sikap konsumen menjadi prediktor dari niat berperilaku agar sesuai dengan Theory of Planned Behavior sehingga motif untuk sehat 
memoderasi pengaruh sikap konsumen, aspek normatif, aspek informasi, dan persepsi kontrol keperilakuan terhadap niat mengonsumsi suplemen multivitamin. Dengan demikian, penelitian ini bertujuan untuk menjelaskan: (1) pengaruh sikap konsumen terhadap niat mengonsumsi suplemen multivitamin di Kota Denpasar, (2) pengaruh aspek normatif terhadap niat mengonsumsi suplemen multivitamin di Kota Denpasar, (3) pengaruh aspek informasi terhadap niat mengonsumsi suplemen multivitamin di Kota Denpasar, (4) pengaruh persepsi kontrol keperilakuan terhadap niat mengonsumsi suplemen multivitamin di Kota Denpasar, (5) peran motif untuk sehat sebagai pemoderasi pengaruh sikap konsumen terhadap niat mengonsumsi suplemen multivitamin di Kota Denpasar, (6) peran motif untuk sehat sebagai pemoderasi pengaruh aspek normatif terhadap niat mengonsumsi suplemen multivitamin di Kota Denpasar, (7) peran motif untuk sehat sebagai pemoderasi pengaruh aspek informasi terhadap niat mengonsumsi suplemen multivitamin di Kota Denpasar, dan (8) peran motif untuk sehat sebagai pemoderasi pengaruh persepsi kontrol keperilakuan terhadap niat mengonsumsi suplemen multivitamin di Kota Denpasar.

Beberapa studi seperti Ren et al. (2011) dan Petraszko (2013) menunjukkan bahwa sikap konsumen berpengaruh positif terhadap niat mengonsumsi suplemen multivitamin. Studi Yap et al. (2014) di Malaysia menunjukkan bahwa sikap konsumen berpengaruh positif dan signifikan terhadap niat mengonsumsi suplemen multivitamin.

$\mathrm{H}_{1}$ : Sikap konsumen berpengaruh positif dan signifikan terhadap niat mengonsumsi suplemen multivitamin. 
Penelitian Yap et al. (2014) di Malaysia menunjukkan bahwa aspek normatif mempunyai peran mempengaruhi niat konsumen untuk mengonsumsi suplemen multivitamin. Moon et al. (2015) melakukan penelitian di Pakistan juga menunjukkan bahwa aspek normatif berpengaruh positif signifikan terhadap niat mengonsumsi suatu produk. Anthony et al. (2016) menunjukkan bahwa aspek normatif berpengaruh positif dan signifikan terhadap niat berperilaku.

$\mathrm{H}_{2}$ : Aspek normatif berpengaruh positif dan signifikan terhadap niat mengonsumsi suplemen multivitamin.

Penelitian Yap et al. (2014) di Malaysia menunjukkan bahwa aspek informasi sebagai faktor yang mempengaruhi niat mengonsumsi suplemen multivitamin. Noor et al. (2014) juga menunjukkan bahwa aspek informasi berpengaruh positif dan signifikan terhadap niat mengonsumsi suplemen multivitamin. Menurut hasil penelitian Chang (2015) membuktikan bahwa aspek informasi sebagai prediktor yang mempengaruhi niat untuk berperilaku.

$\mathrm{H}_{3}$ : Aspek informasi berpengaruh positif dan signifikan terhadap niat mengonsumsi suplemen multivitamin.

Penelitian Ren et al. (2011) menunjukkan hasil bahwa persepsi kontrol keperilakuan berpengaruh positif dan signifikan terhadap niat mengonsumsi suplemen multivitamin. Pickett et al. (2012) membuktikan persepsi kontrol keperilakuan sebagai salah satu prediktor yang mempengaruhi niat mengonsumsi suplemen multivitamin. Demikian juga pada penelitian Noor et al. (2014) di Malaysia menunjukkan bahwa kontrol perilaku berpengaruh positif dan signifikan terhadap niat mengonsumsi suplemen multivitamin.

$\mathrm{H}_{4}$ : Persepsi kontrol keperilakuan berpengaruh positif dan signifikan terhadap niat mengonsumsi suplemen multivitamin. 
Anak Agung Gede Satrya Anggara Putra, Ni Wayan Sri Suprapti, Ni Nyoman Kerti Yasa. Niat.......

Konsumen yang mempunyai motif untuk sehat mampu memperkuat pengaruh sikap konsumen terhadap niat mengonsumsi suplemen multivitamin (Chrysochou dan Grunert, 2014). Penelitian Noor et al. (2014) menunjukkan bahwa motif untuk sehat memoderasi pengaruh sikap konsumen terhadap niat mengonsumsi suplemen multivitamin.

$\mathrm{H}_{5}$ : Motif untuk sehat memoderasi pengaruh sikap konsumen terhadap niat mengonsumsi suplemen multivitamin.

Motif untuk sehat juga ditemukan memoderasi pengaruh aspek normatif terhadap niat mengonsumsi suplemen multivitamin (Noor et al., 2014). Penelitian Frank (2015) dan Young et al. (2016) mengungkapkan motif individu memoderasi pengaruh aspek normatif terhadap niat berperilaku.

$\mathrm{H}_{6}$ : Motif untuk sehat memoderasi pengaruh aspek normatif terhadap niat mengonsumsi suplemen multivitamin.

Dierkes dan von Grote (2005) mengungkapkan bahwa motif seseorang mampu mempengaruhi pengaruh aspek informasi terhadap niat berperilaku. Petrovici and Ritson (2006) membuktikan bahwa seseorang yang memiliki motif untuk sehat lebih memungkinkannya untuk menerima informasi kesehatan dan memiliki niat berperilaku dalam menjaga kesehatannya. Noor et al. (2014) menunjukkan bahwa masuknya motif untuk sehat sebagai variabel pemoderasi mampu memberikan perspektif yang lebih akurat tentang pengaruh aspek informasi terhadap niat mengonsumsi suplemen multivitamin.

$\mathrm{H}_{7}$ : Motif untuk sehat memoderasi pengaruh aspek informasi terhadap niat mengonsumsi suplemen multivitamin.

Berdasarkan kajian pustaka dan penelusuran terhadap sejumlah hasil-hasil studi empiris, maka dapat dibangun sebuah kerangka konseptual sebagai berikut: 


\section{Gambar 1. Kerangka Konseptual Penelitian}

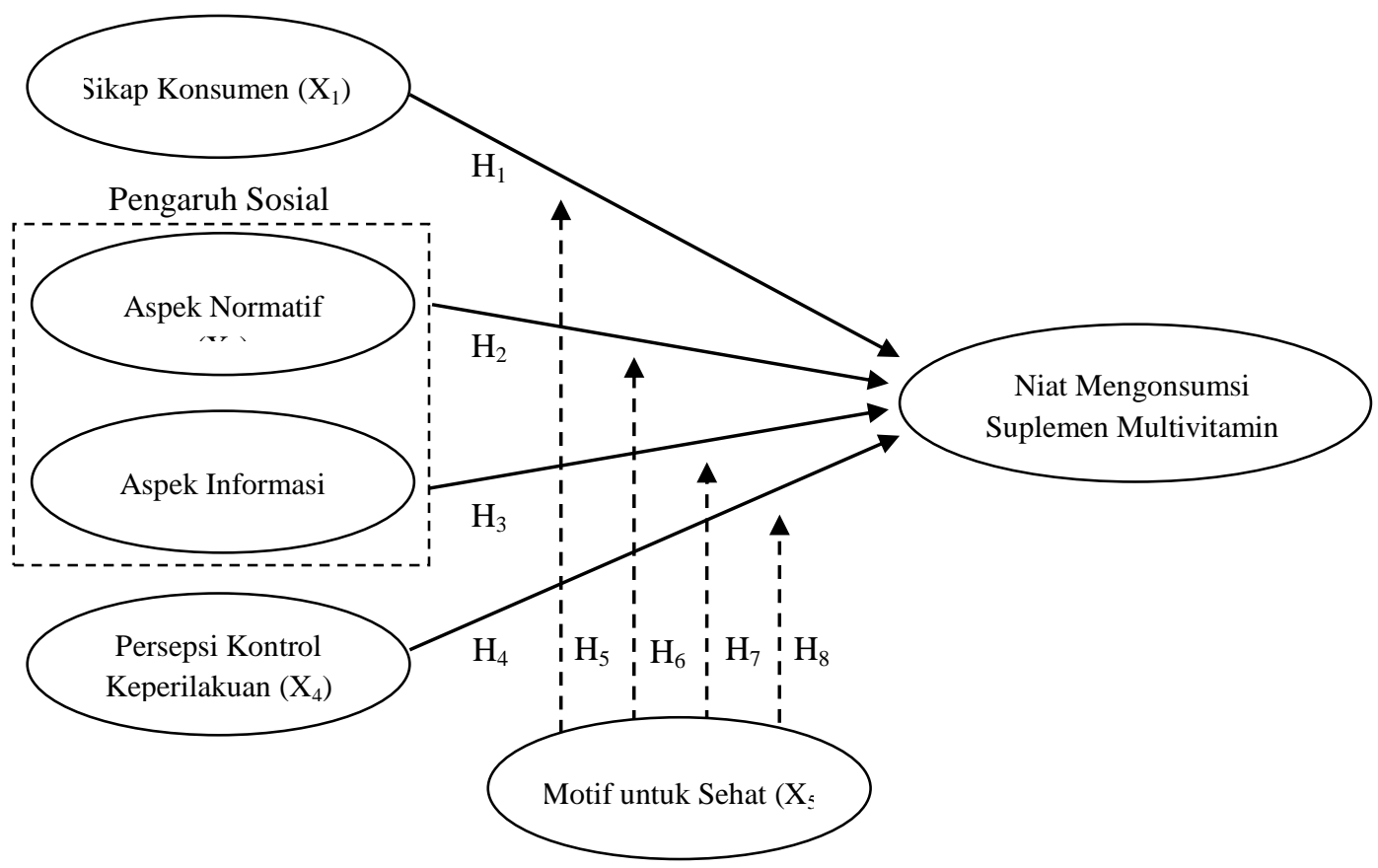

\section{METODE PENELITIAN}

Ruang lingkup penelitian ini adalah niat konsumen lansia mengonsumsi suplemen multivitamin yang diprediksi oleh variabel sikap konsumen, aspek normatif, aspek informasi, dan persepsi kontrol keperilakuan serta motif untuk sehat. Data kuantitatif dan data kualitatif digunakan pada penelitian ini. Pada penelitian ini data kuantitatif berupa data proyeksi jumlah penduduk lansia di Indonesia dan data penjualan produk suplemen multivitamin di Indonesia dari Tahun 2008 sampai Tahun 2013, sedangkan data kualitatif berupa temuan penelitian-penelitian sebelumnya, pendapat responden mengenai sikap konsumen, aspek normatif, aspek informasi, persepsi kontrol keperilakuan, motif untuk sehat, serta niat mengonsumsi suplemen multivitamin. Data-data tersebut diperoleh dari dua sumber, yaitu sumber primer dari para responden, serta sumber sekunder dari literatur dan artikel yang dipublikasikan. 
Penelitian ini menggunakan penduduk lansia yang berdomisili di Kota Denpasar sebagai populasi. Metode nonprobability sampling digunakan sebagai pendekatan dalam menentukan sampel dengan teknik purposive sampling sehingga memiliki kriteria antara lain memiliki umur 60 tahun dan ke atas, berpendidikan sekurang-kurangnya SMA ataupun sederajat, dan berdomisili di Kota Denpasar. Ukuran sampel pada penelitian ini menggunakan pendekatan dari Ferdinand (2006:44), sehingga kriteria ini menghasilkan rentang $19 \times(5-10)=$ 100 - 190. Berdasarkan batasan tersebut, maka penelitian ini mengambil sampel sebanyak 133 responden ( 7 kali 19 indikator $=133$ responden $)$.

Data dikumpulkan menggunakan instrumen kuesioner dan wawancara. Penyebaran kuesioner dilakukan secara pribadi agar dapat membangun hubungan dan respon cukup tinggi dari responden, sehingga responden dengan sukarela memberikan data yang objektif dan cepat. Data yang sudah terkumpul nantinya akan ditabulasi untuk dianalisis menggunakan statistik deskriptif dan statistik inferensial. Analisis deskriptif bertujuan untuk mengetahui karakteristik dan tanggapan responden mengenai item-item pernyataan dalam kuisioner, sedangkan statistik inferensial digunakan untuk menguji kebenaran hipotesis-hipotesis yang telah dirumuskan dengan menggunakan analisis regresi moderasi.

\section{HASIL DAN PEMBASAHAN}

Karakteristik responden dapat dilihat dari variabel jenis kelamin, usia, pendidikan, dan pekerjaan. Jenis kelamin laki-laki mendominasi dalam penelitian ini yang mencapai 59,4 persen, sedangkan 40,6 persen adalah perempuan. Kelompok usia responden didominasi oleh kelompok lansia yang berusia antara 
60-69 tahun dengan persentase 80,5 persen, sedangkan sisanya sebanyak 19,5 persen adalah lansia yang berusia 70 tahun dan keatas. Berdasarkan tingkat pendidikan responden, mayoritas responden berpendidikan tinggi dengan tingkat pendidikan responden didominasi oleh pendidikan SMA/sederajat sebanyak 57,9 persen, Sarjana sebanyak 23,3 persen, Pascasarjana sebanyak 10,5 persen, dan Diploma sebanyak 8,3 persen. Dalam hal pekerjaan, sebagian besar responden adalah pensiun atau tidak bekerja yang mencapai 56,4 persen, wirausaha 25,6 persen, pegawai negeri sipil 11,3 persen, dan paling sedikit adalah pegawai swasta sebesar 6,8 persen.

Uji validitas data penelitian dilakukan melalui analisis faktor konfirmatori, sedangkan uji reliabilitas dilakukan melalui Cronbach's Alpha. Hasil pengujian validitas dan reliabilitas semua variabel yang meliputi nilai factor loading, KMO, explained variance, dan Cronbach's Alpha secara rinci disajikan pada Tabel 1.

Tabel 1

Hasil Uji Validitas dan Reliabilitas

\begin{tabular}{|c|c|c|c|c|c|}
\hline \multirow{2}{*}{\multicolumn{2}{|c|}{ Variabel dan Butir Pernyataan }} & \multirow{2}{*}{$\begin{array}{l}\text { Factor } \\
\text { Loading }\end{array}$} & \multirow{2}{*}{ KMO } & \multicolumn{2}{|c|}{ Explained Cronbach's } \\
\hline & & & & Variance & Alpha \\
\hline \multicolumn{6}{|c|}{ Sikap Konsumen $\left(\mathbf{X}_{1}\right)$} \\
\hline $\mathrm{X}_{1.1}$ & $\begin{array}{l}\text { Saya pikir bahwa mengonsumsi suplemen } \\
\text { multivitamin mampu mencegah timbulnya } \\
\text { penyakit }\end{array}$ & 0,721 & \multirow{4}{*}{0,691} & \multirow{4}{*}{55,999} & \multirow{4}{*}{0,700} \\
\hline $\mathrm{X}_{1.2}$ & $\begin{array}{l}\text { Saya pikir bahwa mengonsumsi suplemen } \\
\text { multivitamin mampu menjaga stamina tubuh }\end{array}$ & 0,806 & & & \\
\hline $\mathrm{X}_{1.3}$ & $\begin{array}{l}\text { Saya pikir bahwa mengonsumsi suplemen } \\
\text { multivitamin mampu meningkatkan daya } \\
\text { tahan tubuh }\end{array}$ & 0,753 & & & \\
\hline $\mathrm{X}_{1.4}$ & $\begin{array}{l}\text { Saya pikir bahwa mengonsumsi suplemen } \\
\text { multivitamin mampu mempercepat proses } \\
\text { penyembuhan setelah sakit }\end{array}$ & 0,711 & & & \\
\hline \multicolumn{6}{|c|}{ Aspek Normatif $\left(\mathbf{X}_{2}\right)$} \\
\hline $\mathrm{X}_{2.1}$ & $\begin{array}{l}\text { Keluarga saya menyarankan } \\
\text { mengonsumsi suplemen multivitamin }\end{array}$ & 0,804 & \multirow{3}{*}{0,615} & \multirow{3}{*}{62,651} & \multirow{3}{*}{0,696} \\
\hline $\mathrm{X}_{2.2}$ & $\begin{array}{lccc}\text { Sahabat saya menyarankan } & \text { untuk } \\
\text { mengonsumsi suplemen multivitamin } & \\
\end{array}$ & 0,864 & & & \\
\hline $\mathrm{X}_{2.3}$ & $\begin{array}{l}\text { Penasehat kesehatan saya menyarankan untuk } \\
\text { mengonsumsi suplemen multivitamin }\end{array}$ & 0,697 & & & \\
\hline
\end{tabular}




\begin{tabular}{|c|c|c|c|c|c|}
\hline \multicolumn{6}{|c|}{ Aspek Informasi $\left(\mathbf{X}_{3}\right)$} \\
\hline & $\begin{array}{l}\text { Saya banyak bertanya kepada orang lain } \\
\text { mengenai manfaat suplemen multivitamin }\end{array}$ & 0,857 & \multirow{3}{*}{0,661} & \multirow{3}{*}{69,035} & \multirow{3}{*}{0,761} \\
\hline$X_{3.2}$ & $\begin{array}{l}\text { Saya banyak bertanya kepada orang lain untuk } \\
\text { memilih suplemen multivitamin yang terbaik }\end{array}$ & 0,753 & & & \\
\hline & $\begin{array}{l}\text { Saya mengamati suplemen multivitamin yang } \\
\text { dikonsumsi oleh orang lain }\end{array}$ & 0,878 & & & \\
\hline \multicolumn{6}{|c|}{ Persepsi Kontrol Keperilakuan $\left(\mathbf{X}_{4}\right)$} \\
\hline & $\begin{array}{l}\text { Saya memiliki kemampuan untuk membeli } \\
\text { suplemen multivitamin }\end{array}$ & 0,784 & \multirow{3}{*}{0,630} & \multirow{3}{*}{60,883} & \multirow{3}{*}{0,664} \\
\hline & $\begin{array}{l}\text { Saya memiliki kesempatan untuk membeli } \\
\text { suplemen multivitamin }\end{array}$ & 0,840 & & & \\
\hline & $\begin{array}{l}\text { Keputusan untuk membeli suplemen } \\
\text { multivitamin sepenuhnya ada di tangan saya }\end{array}$ & 0,712 & & & \\
\hline \multicolumn{6}{|c|}{ Motif Untuk Sehat $\left(\mathbf{X}_{5}\right)$} \\
\hline & $\begin{array}{l}\text { Saya merasa lebih baik mencegah timbulnya } \\
\text { penyakit daripada mengobatinya }\end{array}$ & 0,871 & \multirow{3}{*}{0,734} & \multirow{3}{*}{78,356} & \multirow{3}{*}{0,860} \\
\hline & $\begin{array}{l}\text { Saya berusaha untuk menerapkan gaya hidup } \\
\text { sehat }\end{array}$ & 0,891 & & & \\
\hline & $\begin{array}{l}\text { Saya berusaha menjaga kondisi fisik agar } \\
\text { tetap prima }\end{array}$ & 0,893 & & & \\
\hline \multicolumn{6}{|c|}{ Niat Mengonsumsi Suplemen Multivitamin (Y) } \\
\hline & $\begin{array}{l}\text { Saya akan mencoba mengonsumsi suplemen } \\
\text { multivitamin }\end{array}$ & 0,799 & \multirow{3}{*}{0,687} & \multirow{3}{*}{65,910} & \multirow{3}{*}{0,740} \\
\hline & $\begin{array}{l}\text { Saya berencana mengonsumsi } \\
\text { multivitamin }\end{array}$ & 0,809 & & & \\
\hline & $\begin{array}{l}\text { Saya memiliki keinginan yang kuat untuk } \\
\text { mengonsumsi suplemen multivitamin }\end{array}$ & 0,827 & & & \\
\hline
\end{tabular}

Sumber: Data diolah, 2017

Berdasarkan tabel di atas, seluruh butir pernyataan dari setiap variabel memiliki nilai factor loading > 0,50 sehingga dapat dijelaskan bahwa seluruh indikator valid membentuk masing-masing konstruk atau variabel yaitu sikap konsumen, aspek normatif, aspek informasi, persepsi kontrol keperilakuan, motif untuk sehat, dan niat mengonsumsi suplemen multivitamin. KMO seluruh indikator menunjukkan nilai > 0,50 yang berarti seluruh indikator layak untuk diproses lebih lanjut. Explained variance seluruh indikator juga menunjukkan nilai "Cummulative $\% ">50 \%$, yang berarti seluruh indikator mampu menerangkan keragaman faktor-faktor yang terbentuk. Selanjutnya, Cronbach's Alpha memiliki nilai di atas 0,60 berarti seluruh variabel dinyatakan reliabel. 
Uji asumsi klasik yang harus dipenuhi pada analisis regresi moderasi menghasilkan perhitungan yang lebih akurat dan tepat, antara lain melalui pengujian normalitas dan heterokedastisitas.

1) Uji normalitas

Hasil uji normalitas yang disajikan pada Tabel 2 menunjukkan nilai Test Statistic Kolmogorov-Smirnov adalah 0,059 dengan nilai signifikansi sebesar 0,200. Oleh karena nilai signifikansi uji statistik Kolmogorov-Smirnov lebih besar dari 0,05 maka data penelitian ini terdistribusi secara normal.

Tabel 2

\section{Hasil Uji Normalitas}

\begin{tabular}{lr}
\hline & \multicolumn{2}{c}{ Unstandardized Residual } \\
\hline $\mathrm{N}$ & 133 \\
\hline Kolmogorov-Sminov & 0,059 \\
\hline Asymp. Sig. (2-tailed) & 0,200 \\
\hline
\end{tabular}

Sumber: Data diolah, 2017

2) Uji heterokedastisitas

Hasil uji heterokedastisitas yang disajikan pada Tabel 3 menunjukkan bahwa variabel-variabel dalam penelitian ini memiliki nilai signifikansi mulai dari 0,077 sampai dengan 0,861. Nilai signifikansi yang lebih besar dari 0,05 maka persamaan regresi tidak terjadi gejala heterokedastisitas.

Tabel 3

Hasil Uji Heterokedastisitas

\begin{tabular}{lcc}
\hline \multicolumn{1}{c}{ Variabel } & Sig. & Keterangan \\
\hline Sikap Konsumen $\left(\mathrm{X}_{1}\right)$ & 0,089 & Lulus Uji \\
\hline Aspek Normatif $\left(\mathrm{X}_{2}\right)$ & 0,098 & Lulus Uji \\
\hline Aspek Informasi $\left(\mathrm{X}_{3}\right)$ & 0,514 & Lulus Uji \\
\hline Persepsi Kontrol Keperilakuan $\left(\mathrm{X}_{4}\right)$ & 0,861 & Lulus Uji \\
\hline Motif Untuk Sehat $\left(\mathrm{X}_{5}\right)$ & 0,245 & Lulus Uji \\
\hline Interaksi $\left(\mathrm{X}_{1} \mathrm{X}_{5}\right)$ & 0,086 & Lulus Uji \\
\hline Interaksi $\left(\mathrm{X}_{2} \mathrm{X}_{5}\right)$ & 0,077 & Lulus Uji \\
\hline Interaksi $\left(\mathrm{X}_{3} \mathrm{X}_{5}\right)$ & 0,524 & Lulus Uji \\
\hline Interaksi $\left(\mathrm{X}_{4} \mathrm{X}_{5}\right)$ & 0,760 & Lulus Uji \\
\hline
\end{tabular}

Sumber: Data diolah, 2017 
Anak Agung Gede Satrya Anggara Putra, Ni Wayan Sri Suprapti, Ni Nyoman Kerti Yasa. Niat.......

Pengujian hipotesis dalam penelitian menggunakan analisis regresi moderasi. Hasil analisis regresi moderasi secara rinci disajikan sebagai berikut.

Tabel 4

Hasil Analisis Regresi Moderasi

\begin{tabular}{|c|c|c|c|c|c|c|}
\hline \multirow[t]{2}{*}{ Variabel } & \multicolumn{2}{|c|}{$\begin{array}{c}\text { Unstandardized } \\
\text { Coefficients }\end{array}$} & $\begin{array}{c}\text { Standardized } \\
\text { Coefficients }\end{array}$ & \multirow[t]{2}{*}{ t-hitung } & \multirow[t]{2}{*}{ Nilai p } & \multirow[t]{2}{*}{ Keterangan } \\
\hline & B & Std. Error & Beta & & & \\
\hline (Constant) & 25,180 & 6,706 & & 3,755 & 0,000 & Signifikan \\
\hline Sikap Konsumen $\left(\mathrm{X}_{1}\right)$ & $-1,194$ & 0,471 & $-1,684$ & $-2,535$ & 0,013 & Signifikan \\
\hline Aspek Normatif $\left(\mathrm{X}_{2}\right)$ & $-2,024$ & 0,464 & $-3,457$ & $-4,360$ & 0,000 & Signifikan \\
\hline Aspek Informasi $\left(\mathrm{X}_{3}\right)$ & 1,864 & 0,473 & 3,118 & 3,938 & 0,000 & Signifikan \\
\hline $\begin{array}{l}\text { Persepsi Kontrol } \\
\text { Keperilakuan }\left(\mathrm{X}_{4}\right) \\
\end{array}$ & 0,310 & 0,148 & 0,316 & 2,098 & 0,038 & Signifikan \\
\hline Motif Untuk Sehat $\left(\mathrm{X}_{5}\right)$ & $-1,037$ & 0,458 & $-1,351$ & $-2,264$ & 0,025 & Signifikan \\
\hline Interaksi $\left(\mathrm{X}_{1} \mathrm{X}_{5}\right)$ & 0,096 & 0,034 & 2,946 & 2,845 & 0,005 & Signifikan \\
\hline Interaksi $\left(\mathrm{X}_{2} \mathrm{X}_{5}\right)$ & 0,126 & 0,033 & 3,441 & 3,793 & 0,000 & Signifikan \\
\hline Interaksi $\left(\mathrm{X}_{3} \mathrm{X}_{5}\right)$ & $-0,124$ & 0,033 & $-3,083$ & $-3,700$ & 0,000 & Signifikan \\
\hline Interaksi $\left(\mathrm{X}_{4} \mathrm{X}_{5}\right)$ & $-0,022$ & 0,010 & $-0,523$ & $-2,162$ & 0,033 & Signifikan \\
\hline $\mathrm{F}$ & & & 9,315 & & & Positif \\
\hline Sig. F & & & 0,000 & & & Signifikan \\
\hline$R$ Square & & & 0,405 & & & Tidak Baik \\
\hline
\end{tabular}

Sumber: Data diolah, 2017

Berdasarkan Tabel 4, model penelitian ini memiliki persamaan regresi moderasi sebagai berikut.

$$
\begin{aligned}
\mathrm{Y}= & 25,180-1,194 \mathrm{X}_{1}-2,024 \mathrm{X}_{2}+1,864 \mathrm{X}_{3}+0,310 \mathrm{X}_{4}-1,037 \mathrm{X}_{5}+0,096 \mathrm{X}_{1} \mathrm{X}_{5} \\
& +0,126 \mathrm{X}_{2} \mathrm{X}_{5}-0,124 \mathrm{X}_{3} \mathrm{X}_{5}-0,022 \mathrm{X}_{4} \mathrm{X}_{5}+\mathrm{e}
\end{aligned}
$$

Uji koefisien determinasi dan uji statistik $\mathrm{F}$ dilakukan untuk menguji ketepatan fungsi regresi dalam menaksir nilai aktual. Pada Tabel 4 koefisien determinasi menunjukkan nilai $R$ Square sebesar 0,405. Hal ini berarti sebanyak 40,5 persen variasi niat mengonsumsi suplemen multivitamin dapat dijelaskan oleh variasi dari variabel sikap konsumen, aspek normatif, aspek informasi, persepsi kontrol keperilakuan, motif untuk sehat, interaksi antara sikap konsumen dan motif untuk sehat, interaksi antara aspek normatif dan motif untuk sehat, interaksi antara aspek informasi dan motif untuk sehat, dan interaksi antara 
persepsi kontrol keperilakuan dan motif untuk sehat, sedangkan sisanya 59,5 persen dijelaskan oleh variabel lain di luar model penelitian ini. Pada Tabel 4 menunjukkan nilai $\mathrm{F}$ hitung yang diperoleh sebesar 9,315 dengan signifikansi sebesar 0,000. Hal ini berarti model yang dibangun untuk menjelaskan niat mengonsumsi suplemen multivitamin telah memenuhi unsur kelayakan model sehingga bisa diinterpretasikan lebih lanjut.

\section{Pengaruh sikap konsumen terhadap niat mengonsumsi suplemen multivitamin}

Hasil penelitian menunjukkan bahwa sikap konsumen berpengaruh negatif dan signifikan terhadap niat mengonsumsi suplemen multivitamin dengan nilai koefisien regresi $-1,194$ pada tingkat signifikansi $0,013(\mathrm{p}<0,05)$. Hal ini berarti semakin buruk sikap konsumen untuk mengonsumsi suplemen multivitamin maka semakin tinggi niat mengonsumsi suplemen multivitamin. Berdasarkan hasil wawancara dengan beberapa responden yang memiliki sikap negatif, terungkap bahwa mengonsumsi suplemen multivitamin secara terus menerus dapat mengakibatkan efek ketergantungan dan terjadi resistensi terhadap serangan berbagai virus dan kuman. Namun, para lansia tetap berniat mengonsumsinya karena ingin membuktikan kebenaran dan merasakan konsekuensinya bagi kesehatan tubuhnya.

Hasil penelitian ini berlawanan dengan hipotesis yang dirumuskan tetapi sesuai dengan hasil penelitian Herlis (2012) bahwa sikap konsumen berpengaruh negatif dan signifikan terhadap niat beli private label. Niat beli private label berkurang meskipun konsumen memiliki sikap baik terhadap private label. Hal ini disebabkan oleh harga yang ditawarkan, promosi, kebutuhan akan variasi produk, 
Anak Agung Gede Satrya Anggara Putra, Ni Wayan Sri Suprapti, Ni Nyoman Kerti Yasa. Niat.......

dan ketersediaan produk itu sendiri. Apabila dikaitkan dengan suplemen multivitamin, sikap positif terhadap konsumsi suplemen multivitamin membuat konsumen memandang bahwa semakin baik kualitas suplemen multivitamin dan memiliki banyak manfaat bagi kesehatan maka semakin mahal harga produk suplemen multivitamin tersebut. Harga suplemen multivitamin yang relatif mahal dapat mengurungkan niat konsumen untuk membeli sehingga menurunkan niat untuk mengonsumsinya. Di samping harga, kegiatan promosi yang kurang gencar bisa menimbulkan kurangnya rasa ingin tahu di benak konsumen dan terbatasnya ketersediaan suplemen multivitamin di pasar membuat konsumen mengurungkan niat untuk mengonsumsinya.

Turunnya niat lansia untuk mengonsumsi suplemen multivitamin meskipun lansia memiliki sikap positif terhadap konsumsi suplemen multivitamin dapat disebabkan oleh efek ketergatungan yang ditimbulkan dari suplemen multivitamin secara terus menerus. Jika dikonsumsi secara terus menerus maka dapat mengakibatkan efek samping berbahaya atau menimbulkan ketergantungan. Sebelumnya, Istiana et al. (2008) menjelaskan bahwa pengaruh negatif antara sikap dengan niat konsumen disebabkan oleh tingkat keterlibatan yang dimiliki oleh seseorang. Seseorang yang tidak ingin terlibat atau tidak memiliki dorongan untuk membeli susu UHT, maka niat untuk membeli menjadi berkurang meskipun memiliki sikap positif terhadap pembelian susu UHT. Penelitian Marlyna (2015) menunjukkan bahwa sikap konsumen mempengaruhi niat berperilaku secara negatif dan signifikan. 


\section{Pengaruh aspek normatif terhadap niat mengonsumsi suplemen multivitamin}

Hasil penelitian menunjukkan bahwa aspek normatif berpengaruh negatif dan signifikan terhadap niat mengonsumsi suplemen multivitamin dengan nilai koefisien regresi $-2,024$ pada tingkat signifikansi $0,000(p<0,05)$. Hal ini berarti semakin buruk aspek normatif maka semakin berkurang niat mengonsumsi suplemen multivitamin. Berdasarkan hasil wawancara beberapa responden yang memiliki orang terdekat yang tidak menyarankan untuk mengonsumsi suplemen multivitamin mengungkapkan bahwa orang terdekat mereka lebih menyarankan untuk mengatur pola makan, istirahat yang cukup, dan olahraga ringan setiap hari. Namun, para lansia tidak mau menerima sepenuhnya saran dari orang terdekat seperti keluarga, sahabat, dan penasehat kesehatannya karena mereka memiliki kebebasan untuk berperilaku dan mereka juga yang sepenuhnya mengetahui kondisi kesehatan tubuhnya serta apa yang sebaiknya diperlukan atau dibutuhkan oleh dirinya agar tetap dapat menjaga kesehatannya.

Hasil penelitian ini berlawanan dengan hipotesis yang dirumuskan tetapi sesuai dengan penelitian sebelumnya yang dilakukan oleh Sadachar et al. (2016) di Amerika menunjukkan keputusan seseorang untuk membeli pakaian ramah lingkungan tidak memerlukan saran ataupun persetujuan dari orang terdekatnya. Mereka cenderung ingin tampil berbeda dari orang lain disekitarnya untuk menunjukkan identitas atau jati diri. Demikian juga pada penelitian Koklic (2016) di Slovenia menunjukkan bahwa seseorang tidak memperoleh manfaat apapun apabila melakukan suatu perilaku tertentu sesuai saran dari orang terdekatnya. Alghamdi et al. (2017) dalam penelitiannya di Arab Saudi menunjukkan bahwa 
turunnya niat seseorang untuk mengonsumsi suplemen multivitamin dikarenakan seseorang belum memiliki kesiapan untuk mengonsumsi suplemen multivitamin apabila dirinya masih dalam kondisi sehat dan memperoleh kecukupan asupan gizi dari variasi makanan meskipun orang terdekatnya telah menyarankan untuk mengonsumsi suplemen multivitamin.

\section{Pengaruh aspek informasi terhadap niat mengonsumsi suplemen multivitamin}

Hasil penelitian menunjukkan bahwa aspek informasi berpengaruh positif dan signifikan terhadap niat mengonsumsi suplemen multivitamin dengan nilai koefisien regresi 1,864 pada tingkat signifikansi $0,000(\mathrm{p}<0,05)$. Hal ini berarti semakin baik aspek informasi maka semakin tinggi niat mengonsumsi suplemen multivitamin. Hasil penelitian ini sesuai dengan Al-Naggar dan Chen (2011) yang menunjukkan bahwa seseorang yang memperoleh informasi mengenai manfaat suplemen multivitamin dari orang lain mampu mempengaruhi niat mereka untuk mengonsumsi suplemen multivitamin. Noor et al. (2014) dalam penelitiannya menunjukkan pengaruh positif dan signifikan aspek informasi terhadap niat mengonsumsi suplemen multivitamin. Hal ini sangat dipengaruhi oleh pengamatan yang dilakukan terhadap orang lain yang memperoleh manfaat dari mengonsumsi suplemen multivitamin yang nantinya dapat membentuk niat konsumen untuk mengonsumsi suplemen multivitamin. Yap et al. (2014) juga menunjukkan hasil yang sama dalam penelitiannya di Malaysia, bahwa aspek informasi berpengaruh positif dan signifikan terhadap niat konsumen mengonsumsi suplemen multivitamin. 


\section{Pengaruh persepsi kontrol keperilakuan terhadap niat mengonsumsi suplemen multivitamin}

Hasil penelitian menunjukkan bahwa persepsi kontrol keperilakuan berpengaruh positif dan signifikan terhadap niat mengonsumsi suplemen multivitamin dengan nilai koefisien regresi 0,310 pada tingkat signifikansi 0,038 ( $\mathrm{p}<0,05)$. Hal ini berarti semakin baik persepsi kontrol keperilakuan maka semakin tinggi niat mengonsumsi suplemen multivitamin. Hasil penelitian ini sama seperti penelitian Pawlak et al. (2008) di Amerika yang menunjukkan bahwa seseorang yang memiliki faktor situasional dan internal yang dapat memfasilitasinya dalam mengonsumsi suplemen multivitamin akan mempengaruhi niat orang tersebut untuk mengonsumsinya. Namun, kurangnya akses dan kesempatan yang dimiliki untuk membeli suplemen multivitamin dapat menghambat niatnya untuk mengonsumsi suplemen multivitamin.

Chung et al. (2012) dalam penelitiannya di China menunjukkan bahwa persepsi kontrol keperilakuan mempengaruhi niat untuk mengonsumsi suplemen multivitamin. Mereka mempertimbangkan untuk mengonsumsi suplemen multivitamin apabila mereka yakin memiliki kemampuan daya beli dan akses terhadap suplemen multivitamin. Penelitian Noor et al. (2014) menunjukkan bahwa persepsi kontrol keperilakuan berpengaruh positif dan signifkan terhadap niat mengonsumsi suplemen multivitamin.

\section{Motif untuk sehat memoderasi pengaruh sikap konsumen terhadap niat mengonsumsi suplemen multivitamin}

Hasil penelitian ini menunjukkan bahwa motif untuk sehat mampu memoderasi pengaruh sikap konsumen terhadap niat mengonsumsi suplemen 
multivitamin. Koefisien regresi sikap konsumen bernilai negatif dan koefisien regresi interaksi antara sikap konsumen dengan motif untuk sehat bernilai positif signifikan maka dapat dikatakan motif untuk sehat memperlemah pengaruh negatif sikap konsumen terhadap niat mengonsumsi suplemen multivitamin. Niat mengonsumsi suplemen bertambah dengan adanya motif untuk sehat meskipun seseorang memandang bahwa suplemen multivitamin memiliki harga premium.

Adanya motif untuk sehat membuat seseorang tidak hanya menjaga kesehatan tubuhnya dengan cara mengatur pola makan, istirahat yang cukup, dan olahraga ringan tetapi juga mengonsumsi suplemen multivitamin untuk memenuhi kecukupan vitamin dan mineral yang umumnya tidak dapat dibentuk di dalam tubuh. Seseorang tidak memikirkan biaya yang harus dikeluarkan untuk membeli dan mengonsumsi suplemen multivitamin selama ia berusaha menjaga kondisi fisik tubuhnya agar tetap prima dan mencegah timbulnya berbagai penyakit. Hasil penelitian Noor et al. (2014) di Malaysia menunjukkan bahwa interaksi antara sikap konsumen dengan motif sehat mampu meningkatkan niat konsumen untuk mengonsumsi suplemen multivitamin.

\section{Motif untuk sehat memoderasi pengaruh aspek normatif terhadap niat mengonsumsi suplemen multivitamin}

Hasil penelitian ini menunjukkan bahwa motif untuk sehat mampu memoderasi pengaruh aspek normatif terhadap niat mengonsumsi suplemen multivitamin. Koefisien regresi aspek normatif bernilai negatif dan koefisien regresi interaksi antara aspek normatif dengan motif untuk sehat bernilai positif signifikan maka dapat dikatakan motif untuk sehat memperlemah pengaruh negatif aspek normatif terhadap niat mengonsumsi suplemen multivitamin. 
Meskipun seseorang memiliki kebebasan untuk berperilaku dalam menjaga kesehatannya dan tidak mau menerima sepenuhnya saran dari orang terdekat untuk mengonsumsi suplemen multivitamin, namun seseorang yang memiliki motif untuk sehat cenderung menjaga kesehatannya sesuai saran dari orang terdekatnya dan tidak ingin tampil beda dalam menjaga kesehatannya dari orang terdekatnya.

Seseorang akan menyadari bahwa orang terdekat seperti penasehat kesehatan tahu apa yang sebaiknya dilakukan dan dibutuhkan untuk menjaga kesehatannya, salah satunya dengan mengonsumsi suplemen multivitamin. Adanya motif untuk sehat membuat seseorang menerima saran dari orang terdekat sehingga dapat meningkatkan niat seseorang untuk mengonsumsi suplemen multivitamin. Hasil penelitian Noor et al. (2014) di Malaysia menunjukkan bahwa interaksi antara aspek normatif dengan motif sehat mampu meningkatkan niat konsumen untuk mengonsumsi suplemen multivitamin.

\section{Motif untuk sehat memoderasi pengaruh aspek informasi terhadap niat mengonsumsi suplemen multivitamin}

Hasil penelitian ini menunjukkan bahwa motif untuk sehat mampu memoderasi pengaruh aspek informasi terhadap niat mengonsumsi suplemen multivitamin. Koefisien regresi aspek informasi bernilai positif dan koefisien regresi interaksi antara aspek informasi dengan motif untuk sehat bernilai negatif signifikan maka dapat dikatakan motif untuk sehat memperlemah pengaruh positif aspek informasi terhadap niat mengonsumsi suplemen multivitamin. Seseorang yang memiliki motif untuk sehat cenderung terus menerus mencari informasi 
terkait manfaat suplemen multivitamin dan mengamati perilaku konsumsi suplemen multivitamin orang lain.

Banyaknya informasi yang diperoleh dari orang lain dapat menimbulkan situasi ambigu. Hal ini dikarenakan sebagian orang bisa memberikan penilaian baik terhadap mengonsumsi suplemen multivitamin yang dapat bermanfaat bagi kesehatan tubuh dan sebagian malah memberikan penilaian buruk terhadap mengonsumsi suplemen multivitamin yang mampu menimbulkan risiko atau tidak mempunyai manfaat apapun bagi kesehatan tubuh. Seseorang yang berada dalam situasi ambigu dapat menurunkan niat mengonsumsi suplemen multivitamin. Penelitian ini bertentangan dengan hasil penelitian Noor et al. (2014) di Malaysia yang menunjukkan bahwa motif sehat memperkuat pengaruh aspek informasi terhadap niat mengonsumsi suplemen multivitamin.

\section{Motif untuk sehat memoderasi pengaruh persepsi kontrol keperilakuan terhadap niat mengonsumsi suplemen multivitamin}

Hasil penelitian ini menunjukkan bahwa motif untuk sehat mampu memoderasi pengaruh persepsi kontrol keperilakuan terhadap niat mengonsumsi suplemen multivitamin. Koefisien regresi persepsi kontrol keperilakuan bernilai positif dan koefisien regresi interaksi antara persepsi kontrol keperilakuan dengan motif untuk sehat bernilai negatif signifikan, maka dapat dikatakan motif untuk sehat memperlemah pengaruh positif persepsi kontrol keperilakuan terhadap niat mengonsumsi suplemen multivitamin. Seseorang yang memiliki motif untuk sehat tidak hanya menerapkan gaya hidup sehat dengan mengonsumsi suplemen multivitamin. 
Banyak cara yang dapat digunakan lansia untuk menjaga kondisi fisik agar tetap prima seperti olahraga ringan, mengatur pola makan, istirahat yang cukup, dan menghindari stres berlebih. Seiring bertambahnya usia dan masih aktif dalam bekerja memungkinkan para lansia lupa untuk menerapkan salah satu cara tersebut termasuk mengonsumsi suplemen multivitamin. Hal ini dapat menurunkan niat lansia untuk mengonsumsi suplemen multivitamin karena dikemudian hari rentan lupa dan tidak rutin dalam mengonsumsinya. Namun, penelitian ini bertentangan dengan hasil penelitian Noor et al. (2014) di Malaysia yang menunjukkan bahwa motif sehat memperkuat pengaruh persepsi kontrol keperilakuan terhadap niat mengonsumsi suplemen multivitamin.

\section{SIMPULAN DAN SARAN}

Berdasarkan hasil analisis penelitian dan pembahasan yang telah dipaparkan sebelumnya, maka kesimpulan yang dapat ditarik antara lain: (1) Semakin baik sikap konsumen untuk mengonsumsi suplemen multivitamin, maka semakin rendah niat mengonsumsi suplemen multivitamin, (2) Semakin baik aspek normatif, maka semakin rendah niat mengonsumsi suplemen multivitamin, (3) Semakin baik aspek informasi, maka semakin tinggi niat mengonsumsi suplemen multivitamin, (4) Semakin baik persepsi kontrol keperilakuan, maka semakin tinggi pula niat mengonsumsi suplemen multivitamin, (5) Motif untuk sehat mampu memperlemah pengaruh negatif sikap konsumen terhadap niat mengonsumsi suplemen multivitamin, (6) Motif untuk sehat mampu memperlemah pengaruh negatif aspek normatif terhadap niat mengonsumsi suplemen multivitamin, (7) Motif untuk sehat mampu memperlemah pengaruh 
positif aspek informasi terhadap niat mengonsumsi suplemen multivitamin, (8) Motif untuk sehat mampu memperlemah pengaruh positif persepsi kontrol keperilakuan terhadap niat mengonsumsi suplemen multivitamin.

Saran yang dapat diberikan dari penelitian ini antara lain: (1) Menentukan proporsi sampel penelitian dan menggunakan responden yang lebih luas tidak hanya konsumen lansia tetapi juga konsumen wanita hamil dan pra lansia dalam upaya perilaku menjaga kesehatan, (2) Melakukan pengujian pada faktor lain yang dapat mempengaruhi niat mengonsumsi suplemen multivitamin mengingat nilai $R$ Square yang didapat dalam penelitian ini hanya 40,5\%, (3) Penelitian di masa mendatang perlu memperkaya temuan studi empiris dengan mengkaji perilaku yang berkaitan dalam menjaga kesehatan lainnya seperti makan makanan sehat, (4) Penelitian di masa mendatang perlu mempertimbangkan untuk menggunakan karakteristik demografi misalnya tingkatan kemampuan daya beli dan konsumsi suplemen multivitamin.

\section{IMPLIKASI PENELITIAN}

Secara teoritis, hasil studi ini memberi implikasi terhadap konsep TPB yang diterapkan pada niat konsumen lansia mengonsumsi suplemen multivitamin. Studi ini menunjukkan ada beberapa hubungan kausalitas yang masih belum konsisten dengan hasil penelitian terdahulu. Dengan kata lain, hubungan yang biasanya mengindikasi pengaruh secara positif berbalik menjadi negatif dan signifikan.

Secara praktis hasil studi ini memberi beberapa implikasi. Sikap positif konsumen terhadap konsumsi suplemen multivitamin mampu menurunkan niat 
mengonsumsi suplemen multivitamin. Pihak manajemen perusahaan yang menjual produk suplemen multivitamin setidaknya menghadirkan produk dapat dijangkau sesuai dengan pendapatan para lansia tetapi suplemen tetap memiliki berbagai manfaat bagi kesehatan. Aspek normatif mampu menurunkan niat mengonsumsi suplemen multivitamin. Konsumen lansia tidak selalu menerima dan mengikuti saran untuk mengonsumsi suplemen multivitamin yang berasal dari orang terdekat seperti keluarga, sahabat, dan penasehat kesehatan. Dalam strategi pemasaran, pihak perusahaan sebaiknya mengurangi menggunakan orang terdekat untuk memberikan saran atau anjuran kepada lansia agar mengonsumsi suplemen multivitamin dan menyasar lansia yang ingin tampil beda dari orang terdekatnya dalam perilaku menjaga kesehatan.

Aspek informasi mampu meningkatkan niat mengonsumsi suplemen multivitamin. Konsumen lansia cenderung mencari informasi terkait suplemen multivitamin dan mengamati konsumsi suplemen multivitamin orang lain. Pihak manajemen perusahaan yang menjual produk suplemen multivitamin sebaiknya memberikan informasi yang obyektif terkait manfaat suplemen multivitamin sehingga para lansia memperoleh pemahaman yang lebih baik. Persepsi kontrol keperilakuan mampu meningkatkan niat mengonsumsi suplemen multivitamin. Pihak manajemen perusahaan yang menjual produk suplemen multivitamin disarankan agar menyasar konsumen lansia yang memiliki kemampuan ekonomi untuk membeli suplemen multivitamin, menyediakan suplemen multivitamin pada toko atau apotek yang mudah dijangkau oleh konsumen, dan keputusan untuk membeli sepenuhnya ada di tangan konsumen. 
Motif untuk sehat mampu memperlemah pengaruh sikap konsumen, aspek normatif, aspek informasi, dan persepsi kontrol keperilakuan terhadap niat mengonsumsi suplemen multivitamin. Jika pihak manajemen perusahaan yang menjual produk suplemen multivitamin menyasar konsumen lansia yang memiliki motif untuk sehat maka sebaiknya menyasar konsumen yang memiliki sikap positif terhadap konsumsi suplemen multivitamin dan konsumen yang mau menerima saran orang terdekat untuk mengonsumsi suplemen multivitamin agar dapat meningkatkan niat mengonsumsi suplemen multivitamin. Namun, pihak manajemen harus cermat melihat motif untuk sehat agar informasi yang diterima dan persepsi kontrol keperilakuan yang dimiliki tidak menurunkan niatnya untuk mengonsumsi suplemen multivitamin.

\section{REFERENSI}

Alghamdi, A., M.M. Alghamdi, R.A. Almalki, M.H. Alotaibi, dan A.A. Alshehri. 2017. Prevalence of multivitamins supplement use and associated factors to use it among medical student at Taif University Saudi Arabia. International Journal of Healthcare Sciences. Vol. 4, No. 2, pp. 1150-1158.

Al-Naggar, R.A., dan R. Chen. 2011. Prevalence of vitamin-mineral supplements use and associated factors among young Malaysians. Asian Pacific Journal of Cancer Prevention. Vol. 12, No. 4, pp. 1023-1029.

Anthony, O.A., H.A. Rahim, dan S. Osman. 2016. Relationship between susceptibility to normative influence and purchase intention towards global brands in Nigeria. International Journal of Humanities and Social Science. Vol. 6, No. 3, pp. 163-172.

Austrade. 2014. Exporting Consumer Health Products Indonesia. (online), (http://www.cmaustralia.org.au/resources/Documents/Manufacturing\%20Pag e/Exporting-Consumer-Health-Products-Indonesia-2014-Presentation.pdf) diakses 14 Maret 2016 
Badan Pusat Statistik. 2016. Statistik Penduduk Lanjut Usia. (online), (https://www.bps.go.id/website/pdf_publikasi/Statistik-Penduduk-Lanjut-Usia2015--.pdf) diakses 7 November 2016

Chang, S. 2015. The influence of green viral communications on green purchase intentions: the mediating role of consumers' susceptibility to interpersonal influences. Sustainability: Open Access. Vol. 7, No.5, pp. 4829-4849.

Chrysochou, P., dan K.G. Grunert. 2014. Health-related ad information and health motivation effects on product evaluations. Journal of Business Research. Vol. 67, pp. 1209-1217.

Chung, J., L. Stoel, Y. Xu, dan J. Ren. 2012. Predicting Chinese consumers' purchase intentions for imported soy-based dietary supplements. British Food Journal. Vol. 114, No. 1, pp. 143-161.

Depkes. 2014. Situasi dan Analisis Lanjut Usia. (online), (http://www.depkes.go.id/resources/download/pusdatin/infodatin/infodatinlansia.pdf) diakses 3 Oktober 2016.

Dickinson, A., dan D. MacKay. 2014. Health habits and other characteristics of dietary supplement users: a review. Nutrition Journal. Vol. 13, No. 14, pp. 18 .

Dierkes, M., dan C. von Grote. 2005. Between Understanding and Trust: The Public, Science and Technology, $1^{\text {st }}$ Edition. Inggris: Routledge.

Fatmah. 2006. Respons imunitas yang rendah pada tubuh manusia usia lanjut. Makara Journal of Health Research. Vol. 10, No. 1, pp. 47-53.

Ferdinand, A. 2006. Metode Penelitian Manajemen: Pedoman Penelitian untuk Penulisan Skripsi, Tesis, dan Disertasi Ilmu Manajemen. Semarang: Badan Penerbit Universitas Diponegoro.

Frank, L. 2015. Social norms about a health issue in work group networks. International Journal of Environmental Research and Public Health. Vol. 12, No. 9, pp. 11621-11639.

Grandon, E.E., S.A. Nasco, dan P.P. Mykytyn. 2011. Comparing theories to explain e-commerce adoption. Journal of Business Research. Vol. 64, No. 3, pp. 292-298.

Herlis, Y.R.T. 2012. Analisis pengaruh sikap pada private label brands, brand consciousness, dan consumer perceived value terhadap niat beli private label brand di Lottemart - Surabaya. Jurnal Ilmiah Mahasiswa Manajemen. Vol. 1, No. 4. 
Istiana, L., S. Syahlani, dan S. Nurtini. 2008. Pengaruh Sikap, Norma Subjektif Dan Kontrol Keperilakuan Terhadap Niat Dan Perilaku Beli Produk Susu Ultra High Temperature, Prosiding Lokakarya Nasional Prospek Industri Sapi

Koklic, M.T. 2016. Digital piracy among adults in Slovenia: an application of the theory if interpersonal behavior. Economic And Business Review. Vol. 18, No. 2, pp. 135-150.

Mangleburg, T.F., P.M. Willison, dan T. Bristol. 2004. Shopping with friends and teens' susceptibility to peer influence. Journal of Retailing. Vol. 80, No. 2, pp. 101-116.

Marlyna, D. 2015. Faktor Faktor Determinasi Kecurangan Akademik Dosen Akuntansi di Bandar Lampung. Tesis. Program Pascasarjana Ilmu Akuntansi, Universitas Lampung, Indonesia.

Moon, M.A., M.D. Habib, dan S. Attiq. 2015. Analyzing the sustainable behavioral intentions: Role of norms, beliefs and values on behavioral intentions. Pakistan Journal of Commerce and Social Sciences. Vol. 9, No. 2,

Mynhardt, J. 2009. South African Supplement To Social Psychology, $3^{\text {th }}$ Edition. South African: Pearson.

Noor, N.M.A., S. Yap, K. Liew, dan R. Edwin. 2014. Consumer attitudes toward dietary supplements consumption: Implications for pharmaceutical marketing. International Journal of Pharmaceutical and Healthcare Marketing. Vol. 8 No. 1, pp. 6-26.

Ozer, N. 2012. The Effect of Social Media on Consumer Buying Decision Process. Tesis. Program Magister Manajemen, Universitas Irlandia, Republik Irlandia.

Pawlak, R., D. Brown, M.K. Meyer, C. Connell, K. Yadrick, J.T. Johnson, dan A. Blackwell. 2008. Theory of planned behavior and multivitamin supplement use in caucasian college females. The Journal of Primary Prevention. Vol. 29, No. 1, pp. 57-71.

Penz, E., dan M. Hogg. 2011. The role of mixed emotions in consumer behaviour: Investigating ambivalence in consumers' experiences of approach-avoidance conflicts in online and offline settings. European Journal of Marketing. Vol. 45, No. 1, pp. 104-132.

Petraszko, H. 2013. Theory of Planned Behavior to Predict Multivitamin/Mineral Use. Tesis. Program Magister Sains, Universitas Michigan Timur, Amerika Serikat. 
Petrovici, D.A., dan C. Ritson. 2006. Factors influencing consumer dietary health preventative behaviours. BMC Public Health. Vol. 6, No. 3, pp. 222-233.

Pickett, L.L., H.J. Ginsburg, R.V. Mendez, D.E. Lim, K.R. Blankenship, L.E. Foster, D.H. Lewis, S.W. Ramon, B.M. Saltis, dan S. B. Sheffield. 2012. Ajzen's theory of planned behavior as it relates to eating disorders and body satisfaction. North American Journal of Psychology. Vol. 14, No. 2, pp. 339354.

Ren, J., J. Chung, L. Stoel, dan Y. Xu. 2011. Chinese dietary culture influences consumers' intention to use imported soy-based dietary supplements: an application of the theory of planned behavior. International Journal of Consumer Studies. Vol. 35, No. 6, pp. 661-669.

Sadachar, A., A. Khare, dan S. Manchiraju. 2016. The role of consumer susceptibility to interpersonal influence in predicting green apparel consumption behavior of american youth. Atlantic Marketing Journal. Vol. 5, No. 1, pp. 2165-3887.

Saud, I.M. 2016. Pengaruh sikap dan persepsi kontrol perilaku terhadap niat whistleblowing internal-eksternal dengan persepsi dukungan organisasi sebagai variabel pemoderasi. Jurnal Akuntansi dan Investasi. Vol. 17, No. 2 , pp. 209-219

Siahaan, S., Ujang S., dan Dodik N. 2015. Faktor-faktor yang memengaruhi niat menggunakan kecap lokal. Jurnal Ilmu Keluarga \& Konsumen. Vol. 8, No. 2, pp: $125-132$.

Silvera, D.H., A.M. Lavack, dan F. Kropp. 2008. Impulse buying: the role of affect, social influence, and wellbeing. Journal of Consumer Marketing. Vol. 25, No. 1, pp. 23-33.

Tang, J., dan C. Farn. 2005. The effect of interpersonal influence on softlifting intention and behaviour. Journal of Business Ethics. Vol. 56, No. 2, pp. 149161.

Yap, S., N.A. Noor, R. Marshall, dan K. Liew. 2014. Promoting preventive health behaviour among young Malaysian consumers: toward an integrated conceptual framework. Australasian Marketing Journal. Vol. 22, No. 3, pp. 268-278.

Young, C.M., Neighbors C., DiBello A.M., Sharp C., Zvolensky M.J., dan Lewis M.A. 2016. Coping motives moderate efficacy of personalized normative feedback among heavy drinking U.S. college students. Journal of Studies on Alcohol And Drugs. Vol. 77, No. 3, pp. 495-499. 
Anak Agung Gede Satrya Anggara Putra, Ni Wayan Sri Suprapti, Ni Nyoman Kerti Yasa. Niat.......

Zychowicz, M., dan M. Pilska. 2006. Psychosocial determinants of using vitamin and mineral supplements among students. Polish Journal of Food And Nutrition Sciences. Vol. 15, No. 56, pp. 167-170. 